\title{
Synthesis of a mannose-capped disaccharide with a thiol terminus
}

\author{
Chao Wang, ${ }^{\mathrm{a}}$ Yuan-lin Zhou, ${ }^{\mathrm{a}}$ and David C. Baker ${ }^{\mathrm{b}}$ * \\ ${ }^{a}$ School of Material Science and Engineering, Southwest University of Science and Technology, \\ Mianyang, Sichuan 621010, China \\ ${ }^{b}$ Department of Chemistry, University of Tennessee, Knoxville, TN 37996-1600, USA \\ E-mail: dcbaker@utk.edu
}

\begin{abstract}
The synthesis of a mannose-capped disaccharide containing a thiol-terminated aglycon was carried out to provide a tethered sugar suitable for attaching to gold nanoparticles to mimic carbohydrate-involved cell-surface interactions. The molecule was constructed via Schmidt glycosylation of an appropriately protected glycosyl donor and an acceptor, followed by radical addition to introduce a thiol-terminated aglycon. Subsequent removal of the $N$-phthaloyl protective group followed by $\mathrm{N}$-acetylation afforded the corresponding disaccharide $\mathbf{1 0}$. Removal of the $O$-acetyl groups and purification gave the desired target disaccharide $\mathbf{1 1}$ in an excellent yield, thus furnishing a sample needed for gold nanoparticle development.
\end{abstract}

Keywords: Carbohydrate, mannose, glycosylation, thiol

\section{Introduction}

Cell-surface oligosaccharides contribute to specific cell-cell contacts mainly by interactions with proteins (termed lectins). ${ }^{1}$ There is also evidence that cells use attractive forces between surface oligosaccharides as a mechanism for cell adhesion and recognition. ${ }^{2,3}$ Such interactions are essential for proper development and higher order function in living systems. An improved understanding of the structure of this carbohydrate landscape and how it affects cell recognition will have a direct impact in fields such as immunology, virology, developmental biology, and biomineralization, where events at the cell surface level play a crucial role. ${ }^{4}$ High specificity and low affinity are characteristic features of these carbohydrate-involved interactions. ${ }^{5}$ However, the main challenge to study them is the extremely low affinity of binding. To compensate, multivalent presentation of carbohydrate ligands seems to be a mandatory requirement if one needs to study these interactions quantitatively. ${ }^{5}$

As a result, the interest in designing multivalent carbohydrate analogues that will mimic the natural cell surface and bind with high affinity to lectins, has been steadily growing. Synthetic 
oligosaccharides that are elongated with a suitable spacer have been conjugated to carrierproteins, ${ }^{6}$ dendrimers, ${ }^{7}$ and polystyrenes. ${ }^{8}$ Recently, inert water-soluble gold glyconanoparticles have been successfully applied as multivalent systems for transmission electron microscopic (TEM) studies on the self-recognition of $\mathrm{Le}^{\mathrm{x}}$ antigen, ${ }^{9}$ and the mannose binding to E. coli FimH adhesin. ${ }^{10}$ Their results suggested that the globular shape and the multivalent display of oligosaccharides at the particle surface made gold glyconanoparticles an extremely suitable tool to overcome the low binding affinity of monomeric oligosaccharides to lectins. ${ }^{11,12}$ In addition, gold nanodots, multivalently coated with thiol spacers containing saccharides via covalent linkages of sulfur atoms to the gold surface, are challenging stable probes for studying carbohydrate-involved interactions. ${ }^{13,14}$ In some in-vitro and in-vivo bio-assays, gold glyconanoparticles also showed exceptionally low cytotoxic activities. ${ }^{15}$

Herein, we report the synthetic part of an ongoing project, the synthesis of a mannose-capped disaccharide, derivatized with a thiol terminus at the reducing end. According to the overall project, the synthesized disaccharide will be encapsulated to the gold nanoparticles (termed mAuNP). This tool may provide quantitative understanding of the complex carbohydrate-involved cell-cell interactions, and in the future may give new insights for the development of new pharmaceutically active agents.

\section{Results and Discussion}

\section{Synthetic approaches}

Approaches to the desired disaccharide involve the thiol introduction to a furnished disaccharide backbone. The backbone could be reliably constructed by Schmidt's glycosylation of properly protected glycosyl donors and acceptors. ${ }^{16}$ Meanwhile, methods for thiol introduction vary. Among them, the most widely used ones are by radical addition of a dithiol to the double bond advocated by Vliegenthart and co-workers, ${ }^{17}$ and by reductive amination of the anomeric carbon advocated by Kamerling and co-workers. ${ }^{15}$ Kamerling's method of reductive amination not only introduced a thiol amine, but also undesirably opened the hemiacetal ring structure of the reducing moiety, which made the sample not ideal for subsequent m-AuNP development. On the other hand, in order to clarify relationships between reactivity and protective groups, Vliegenthart's method was preliminarily studied with $N$-acetylglucosamine substrates bearing various protective groups. These results demonstrated that substrates with $N$-phthaloyl protective group were most suitable for glycosylation and radical addition reactions. Therefore, the $\mathrm{N}$ phthaloyl protection would be introduced on the start, and after glycosylation and thiol addition, it would be converted back to the $N$-acetyl group for better interaction with lectins used in the future. By applying this strategy, the synthesis of the targeted thiol-terminated disaccharide was carried out as described in the following sections. 


\section{Synthesis of disaccharide 8}

Allyl $\beta$-glycoside 1 was prepared by a known procedure. ${ }^{18}$ The protected sugar $\mathbf{1}$, Scheme 1 , was subjected to Zemplén conditions to remove all $O$-acetyl groups in quantitative yield. The resulting triol $2^{19}$ was reacted without further purification with anisaldehyde dimethyl acetal (ADMA ) under mildly acidic conditions to give the 4,6-O-benzylidene protected compound $\mathbf{3}^{20}$ It was found that compound $\mathbf{3}$ had low solubility in commonly used glycosylating solvents such as $\mathrm{CH}_{2} \mathrm{Cl}_{2}$ possibly due to the rigidity of the fused-ring structure; therefore, an alternative acceptor with a less rigid structure was prepared.
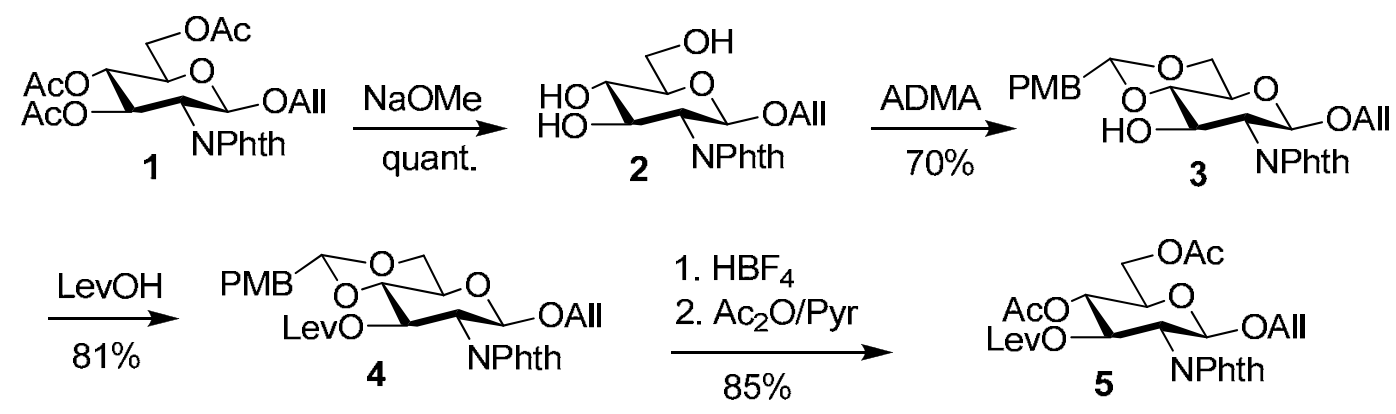
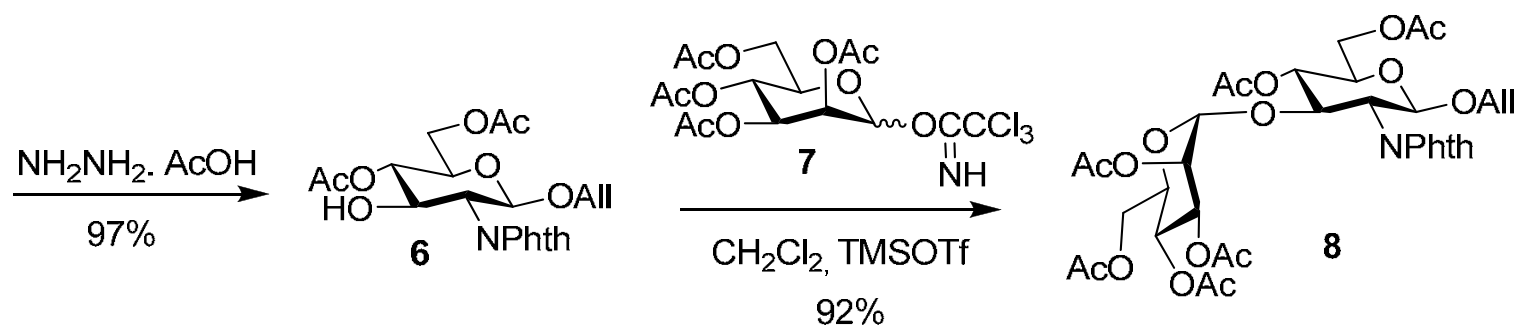

Scheme 1. Synthesis of disaccharide 8.

As a result, the free 3-OH group of 3 was temporarily protected by a levulinoyl group formed by reaction of levulinic acid and 1-(3-dimethylaminopropyl)-3-ethylcarbodiimide hydrochloride (EDCI) under catalysis of 4-(dimethylamino) pyridine. Acidic 4,6-O-benzylidene ring opening with tetrafluoroboric acid and subsequent acetylation with acetic anhydride and pyridine then gave 5. Delevulinoylation of $\mathbf{5}$ by hydrazine acetate ${ }^{21}$ gave the acetylated acceptor $\mathbf{6}$ with significantly improved solubility in commonly used glycosylating solvents.

The mannosyl trichloroacetimidate donor 7 was synthesized by Tosin and Murphy's procedure. $^{22}$ When both acceptor 6 and donor 7 were available, Schmidt glycosylation ${ }^{16}$ was carried out to obtain the protected disaccharide 8. The typical reaction conditions of Schmidt glycosylation involve the use of $4 \AA$ molecular sieves as a drying agent before the moisturesensitive catalyst (TMSOTf) is applied. After several low-yielding trials by using the beads of 4 $\AA$ molecular sieves in our laboratory, we found that the pulverization followed by heat activation of the resulting powder was critical in order to achieve a good yield in this reaction. With a helpful premix-predry technique, the glycosylation yield was finally improved to an excellent $92 \%$. 


\section{Installation of thiol terminus and deprotection}

As shown in Scheme 2, treatment of disaccharide 8 with a dithiol in 1,4-dioxane, after radical initiation by AIBN and three hours of heating, installed the thiol spacer as expected in 9 . Since the subsequent m-AuNP developments require the presence of an $N$-acetyl group to better mimic the natural carbohydrates on cell surfaces, the 2- $N$-phthaloyl group had to be converted to the 2$\mathrm{N}$-acetyl group at this stage. According to Fairbanks and co-workers, ${ }^{23}$ removal of phthalimide protection by ethylenediamine and subsequent re-acetylation by acetic anhydride and pyridine furnished acetamide $\mathbf{1 0}$ in a $62 \%$ yield. Finally, global deprotection under Zemplén conditions gave the thiol-terminated mannose-capped disaccharide $\mathbf{1 1}$ in pure form after GPC purification and subsequent silica gel column chromatography. It is well known that thiols are very likely to dimerize. To reduce this effect in the thiol addition step, some precautions were taken. Firstly, argon was used in the reaction to minimize oxygen's effect on the oxidative dimerization. Secondly, the solvent (1,4-dioxane) must be carefully dried and distilled. Thirdly, before addition to the reaction mixture, 2-mercaptoethanethiol must be distilled to eliminate the disulfide and other impurities formed during the storage period. Under these conditions, the product was formed and isolated as a monomer. However, after a couple of months of storage in vials, a considerable amount of dimer was formed and detected by mass spectrometry. As a result, pretreatment with a reducing agent $\left(\mathrm{NaCNBH}_{3}\right)$ to regenerate the thiol group was required before the compound was used on the coating of gold nanoparticles.
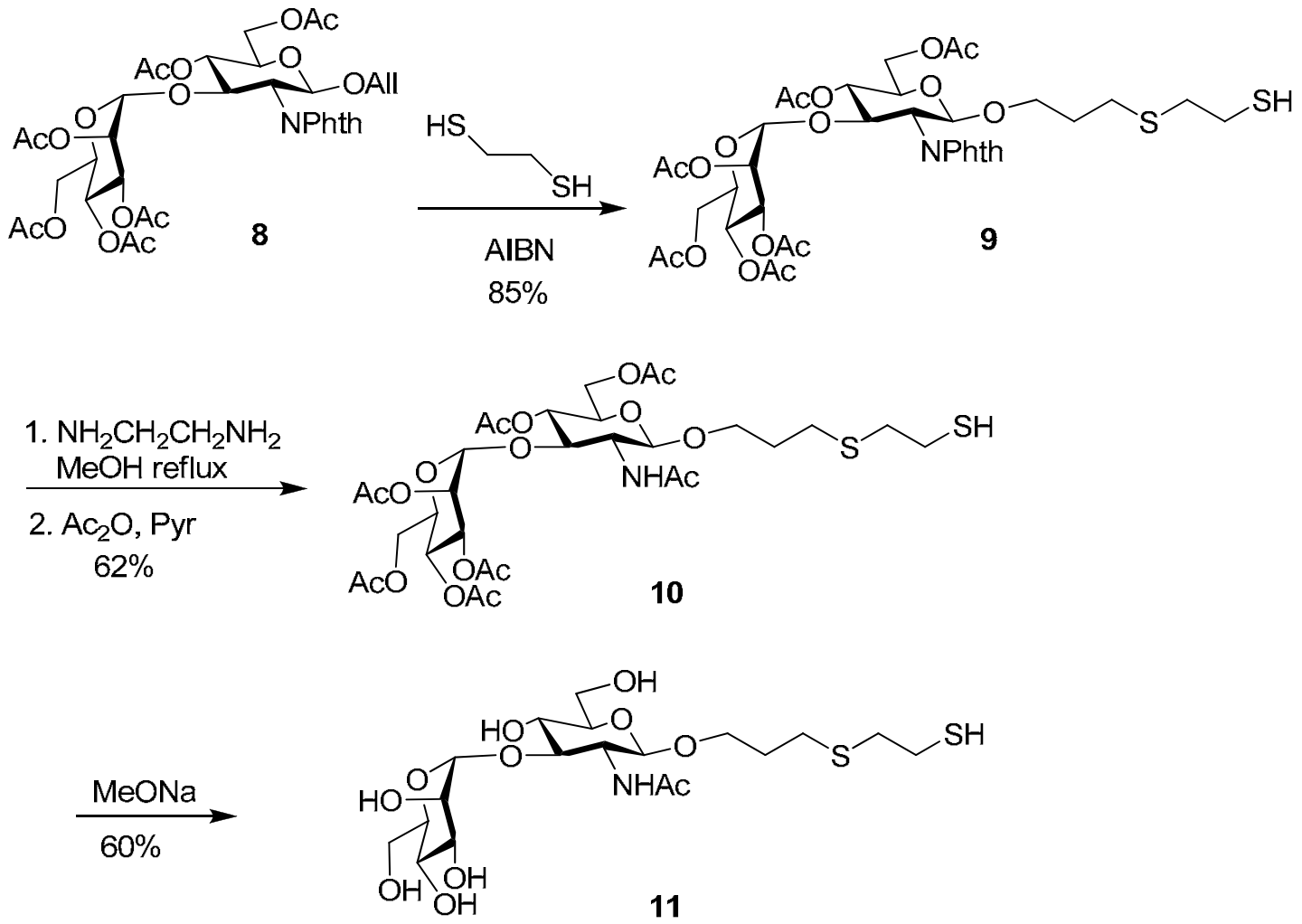

Scheme 2. Installation of thiol terminus and deprotection. 


\section{Conclusions}

The synthesis of a mannose-capped disaccharide with a thiol-terminated aglycon was carried out to provide a tethered sugar suitable for attachment to gold nanoparticles. The designed molecule was synthesized via Schmidt glycosylation using a properly protected glycosyl donor and acceptor, followed by thiol addition to the terminal double-bond of an allyl group at the reducing end of the disaccharide. After removal of the $\mathrm{N}$-phthalimido group and $\mathrm{N}$-acetylation, followed by O-deacetylation and application of a facile purification protocol, the target disaccharide was produced in an excellent yield.

\section{Experimental Section}

General. ${ }^{1} \mathrm{H}(250 \mathrm{MHz}, 300 \mathrm{MHz}$ and $600 \mathrm{MHz})$ and ${ }^{13} \mathrm{C}(62.5 \mathrm{MHz}, 75 \mathrm{MHz}$ and $150 \mathrm{MHz})$ NMR spectra were recorded at $25{ }^{\circ} \mathrm{C}$ with a Bruker AC 250, a Varian Mercury 300 or a Varian Inova 600 instrument. Chemical shifts are given in $\delta$-units (ppm) relative to an internal standard of TMS for ${ }^{1} \mathrm{H}$, and relative to the signal for $\mathrm{CDCl}_{3}(\delta 77.0)$ or DMSO- $d_{6}(\delta 39.5)$ for ${ }^{13} \mathrm{C}$, unless otherwise stated. Apparent first-order multiplicities are indicated by s, singlet; d, doublet; dd, doublet of doublets; $\mathrm{t}$, triplet; dt, doublet of triplets; q, quartet; m, multiplet. All two-dimensional experiments (gCOSY, gHSQC and TOCSY) were recorded with a Varian Inova 600 instrument. Column chromatography was performed on $60 \AA ̊$ ( $40-63 \mu \mathrm{m})$ silica gel (Sorbent Technologies), and fractions were monitored by TLC on Silica Gel $60 \mathrm{~F}_{254}(0.2-\mathrm{mm}$ aluminum-backed plates, E. Merck) by detection with $254 \mathrm{~nm}$ UV light and then spray-heat development using a $p$ anisaldehyde-sulfuric acid reagent. High-resolution ESI mass spectra were obtained on quadrupole time-of-flight instrument (Q-Star-TOF) in the electrospray-ionization mode. Highresolution DART mass spectra were obtained on a JEOL AccuTOF-DART workstation with an ESI source. MALDI-TOF mass spectra were obtained on a Voyager-DE PRO BioSpectrometry Workstation. Optical rotations were carried out at the sodium D line in a $1-\mathrm{dm}$ cell at $25^{\circ} \mathrm{C}$; units are $($ degrees $\mathrm{mL}) /(\mathrm{g} \mathrm{dm})$. All solvents were dried and distilled by standard methods unless otherwise stated.

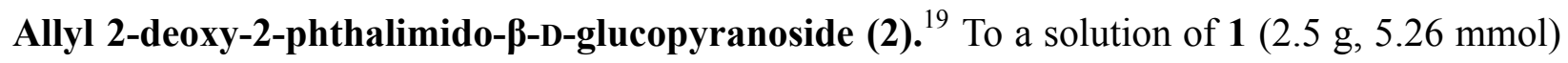
in dry $\mathrm{CH}_{2} \mathrm{Cl}_{2}(10 \mathrm{~mL})$ and dry $\mathrm{MeOH}(50 \mathrm{~mL})$ was added $\mathrm{NaOMe}(25 \%$ in $\mathrm{MeOH}, 0.5 \mathrm{~mL})$. The reaction was stirred at r.t. for $1 \mathrm{~h}$, after which time the reaction was neutralized with Dowex $50 \times 2-100\left(\mathrm{H}^{+}\right.$form $)$. The suspension was filtered and evaporated to afford triol $\mathbf{2}$ as a white solid (1.83 g, quant.), which was used in the next step without further purification. ${ }^{1} \mathrm{H}$ NMR (250 $\left.\mathrm{MHz}, \mathrm{CD}_{3} \mathrm{OD}\right): \delta 7.89-7.79(\mathrm{~m}, 4 \mathrm{H}), 5.71(\mathrm{~m}, 1 \mathrm{H}), 5.20(\mathrm{~d}, J=8.5 \mathrm{~Hz}, 1 \mathrm{H}), 5.09(\mathrm{~d}, J=17.0 \mathrm{~Hz}$, $1 \mathrm{H}), 4.98(\mathrm{~d}, J=10.2 \mathrm{~Hz}, 1 \mathrm{H}), 4.27(\mathrm{~m}, 1 \mathrm{H}), 4.07-3.86(\mathrm{~m}, 4 \mathrm{H}), 3.74(\mathrm{~m}, 1 \mathrm{H}), 3.42-3.30(\mathrm{~m}$, $2 \mathrm{H}) .{ }^{13} \mathrm{C}$ NMR $\left(62.5 \mathrm{MHz}, \mathrm{CD}_{3} \mathrm{OD}\right): \delta 189.63,169.99,135.61,135.26,133.09,124.10,117.35$, 98.92, 78.38, 72.69, 70.76, 62.82, 58.61. 
Allyl 2-deoxy-4,6-O-p-methoxybenzylidene-2-phthalimido- $\beta$-D-glucopyranoside $\quad(3))^{20}$ A mixture of thiol 2 (596 mg, $1.71 \mathrm{mmol})$, ADMA (0.696 mL, $4.09 \mathrm{mmol})$, TsOH (10 mg) and $\mathrm{MeCN}(5 \mathrm{~mL})$ was stirred at r.t. for $8 \mathrm{~h}$, after which time $1 \mathrm{~mL}$ of TEA was added to adjust the $\mathrm{pH}$ to 8 , and the solution was evaporated to dryness. The residue was purified by silica gel column chromatography $\left(2: 1\right.$ hexane-EtOAc) to give $3(558 \mathrm{mg}, 70 \%)$ as a white solid. ${ }^{1} \mathrm{H}$ NMR $\left(250 \mathrm{MHz}, \mathrm{CDCl}_{3}\right): \delta 7.86-7.70(\mathrm{~m}, 4 \mathrm{H}), 7.42(\mathrm{~d}, J=8.5 \mathrm{~Hz}, 2 \mathrm{H}), 6.89(\mathrm{~d}, J=8.5 \mathrm{~Hz}, 2 \mathrm{H}), 5.68$ $(\mathrm{m}, 1 \mathrm{H}), 5.52(\mathrm{~s}, 1 \mathrm{H}), 5.29(\mathrm{~d}, J=8.25 \mathrm{~Hz}, 1 \mathrm{H}), 5.13(\mathrm{~d}, J=17.3 \mathrm{~Hz}, 1 \mathrm{H}), 5.04(\mathrm{~d}, J=11.3 \mathrm{~Hz}$, $1 \mathrm{H}), 4.61(\mathrm{t}, J=8.75 \mathrm{~Hz}, 1 \mathrm{H}), 4.39-4.22(\mathrm{~m}, 3 \mathrm{H}), 4.15-3.99(\mathrm{~m}, 2 \mathrm{H}), 3.80(\mathrm{~s}, 3 \mathrm{H}), 3.63-3.54(\mathrm{~m}$, 2H). ${ }^{13} \mathrm{C}$ NMR $\left(62.5 \mathrm{MHz}, \mathrm{CDCl}_{3}\right): \delta 191.89,160.28,134.08,133.33,131.65,129.46,127.62$, 123.45, 117.58, 113.72, 101.85, 97.95, 82.17, 70.10, 68.66, 68.55, 66.13, 56.53, 55.30. HRDARTMS: Calcd for $\mathrm{C}_{25} \mathrm{H}_{25} \mathrm{NO}_{8} \mathrm{~m} / \mathrm{z} 467.1575$; $[\mathrm{M}+\mathrm{H}]^{+} \mathrm{m} / \mathrm{z} 468.1653$ (calcd 468.1658).

Allyl 2-deoxy-3-O-levulinoyl-4,6-O-p-methoxybenzylidene-2-phthalimido- $\beta$-D-glucopyranoside (4). To a suspension of $\mathbf{3}(755 \mathrm{mg}, 1.62 \mathrm{mmol})$ in dry $\mathrm{CH}_{2} \mathrm{Cl}_{2}(25 \mathrm{~mL})$ were added levulinic acid (282 mg, $2.43 \mathrm{mmol}$ ), EDCI (404 mg), and a catalytic amount of DMAP (10 $\mathrm{mg}$ ). The reaction was stirred at r.t. overnight, and then quenched with water and extracted with $\mathrm{CH}_{2} \mathrm{Cl}_{2}$. The organic phase was dried with anhyd $\mathrm{MgSO}_{4}$ and evaporated to dryness. The residue was submitted to silica gel column chromatography (2:1 hexane-EtOAc) to give compound $\mathbf{4}$ as a white solid (740 mg, 81\%). ${ }^{1} \mathrm{H}$ NMR (250 MHz, $\left.\mathrm{CDCl}_{3}\right): \delta 7.88-7.70(\mathrm{~m}, 4 \mathrm{H}), 7.38(\mathrm{~d}, J=8.75$ $\mathrm{Hz}, 2 \mathrm{H}), 6.87(\mathrm{~d}, J=8.75 \mathrm{~Hz}, 2 \mathrm{H}), 5.92(\mathrm{t}, J=8.75 \mathrm{~Hz}, 1 \mathrm{H}), 5.68(\mathrm{~m}, 1 \mathrm{H}), 5.49(\mathrm{~s}, 1 \mathrm{H}), 5.43$ (d, $J=8.5 \mathrm{~Hz}, 1 \mathrm{H}), 5.13(\mathrm{~d}, J=17.5 \mathrm{~Hz}, 1 \mathrm{H}), 5.04(\mathrm{~d}, J=12.5 \mathrm{~Hz}, 1 \mathrm{H}), 4.41-4.24(\mathrm{~m}, 3 \mathrm{H}), 4.07-$ $3.99(\mathrm{~m}, 2 \mathrm{H}), 3.87-3.68(\mathrm{~m}, 2 \mathrm{H}), 3.78(\mathrm{~s}, 3 \mathrm{H}), 2.60-2.34(\mathrm{~m}, 4 \mathrm{H}), 1.88(\mathrm{~s}, 3 \mathrm{H}) .{ }^{13} \mathrm{C}$ NMR $(62.5$ $\left.\mathrm{MHz}, \mathrm{CDCl}_{3}\right): \delta 205.57,191.66,171.85,160.06,133.96,133.15,131.57,129.36,127.51,123.50$, $117.74,113.51,101.47,97.78,79.26,70.29,69.68,68.56,66.17,55.22,55.08,37.65,29.33$, 27.78. HRDARTMS: Calcd for $\mathrm{C}_{30} \mathrm{H}_{31} \mathrm{NO}_{10} \mathrm{~m} / \mathrm{z}$ 565.1942; $[\mathrm{M}+\mathrm{H}]^{+} \mathrm{m} / \mathrm{z} 566.2020$ (calcd 566.2026).

Allyl 4,6-di-O-acetyl-2-deoxy-3-O-levulinoyl-2-phthalimido- $\beta$-D-glucopyranoside (5). To a solution of 4 (555 mg, $0.982 \mathrm{mmol})$ in $\mathrm{MeOH}(15 \mathrm{~mL})$ and $\mathrm{CH}_{2} \mathrm{Cl}_{2}(3 \mathrm{~mL})$ was added two drops of $\mathrm{HBF}_{4}$. The reaction mixture was stirred at r.t. for $2 \mathrm{~h}$. When TLC showed complete consumption of the starting material and formation of a new spot, the reaction was quenched with TEA and the solution was evaporated to dryness. The resulting diol was redissolved in dry pyridine $(30 \mathrm{~mL})$ and treated with $\mathrm{Ac}_{2} \mathrm{O}(30 \mathrm{~mL})$ at r.t. for $10 \mathrm{~h}$, after which time the reaction mixture was diluted with $\mathrm{CH}_{2} \mathrm{Cl}_{2}$ and poured into ice water. The mixture was then extracted with $3 \times 60 \mathrm{~mL}$ of $\mathrm{CH}_{2} \mathrm{Cl}_{2}$, and the combined organic phase was washed successively with dilute $\mathrm{HCl}$ and satd $\mathrm{NaHCO}_{3}$. The organic phase was dried with anhyd $\mathrm{MgSO}_{4}$ and evaporated to dryness. The residue was submitted to silica gel column chromatography (1:1 hexane-EtOAc) to give compound 5 as a white solid (445 mg, 85\%). ${ }^{1} \mathrm{H}$ NMR $\left(300 \mathrm{MHz}, \mathrm{CDCl}_{3}\right): \delta 7.81-7.67(\mathrm{~m}, 4 \mathrm{H})$, $5.78(\mathrm{t}, J=9.0 \mathrm{~Hz}, 1 \mathrm{H}), 5.66(\mathrm{~m}, 1 \mathrm{H}), 5.35(\mathrm{~d}, J=8.7 \mathrm{~Hz}, 1 \mathrm{H}), 5.14(\mathrm{~d}, J=9.9 \mathrm{~Hz}, 1 \mathrm{H}), 5.10(\mathrm{~d}$, $J=5.1 \mathrm{~Hz}, 1 \mathrm{H}), 5.03(\mathrm{td}, J=7.2 \mathrm{~Hz}, J=1.5 \mathrm{~Hz}, 1 \mathrm{H}), 4.32-4.25(\mathrm{~m}, 3 \mathrm{H}), 4.15(\mathrm{td}, J=12.3 \mathrm{~Hz}, J$ $=2.4 \mathrm{~Hz}, 1 \mathrm{H}), 4.01(\mathrm{dd}, J=12.9 \mathrm{~Hz}, J=6.3 \mathrm{~Hz}, 1 \mathrm{H}), 3.81(\mathrm{~m}, 1 \mathrm{H}), 2.50(\mathrm{~m}, 2 \mathrm{H}), 2.28(\mathrm{~m}, 2 \mathrm{H})$, $2.07(\mathrm{~s}, 3 \mathrm{H}), 2.02(\mathrm{~s}, 3 \mathrm{H}), 1.93(\mathrm{~s}, 3 \mathrm{H}) .{ }^{13} \mathrm{C} \mathrm{NMR}\left(75 \mathrm{MHz}, \mathrm{CDCl}_{3}\right): \delta 205.67,171.66,170.69$, 
$169.69,134.07,133.21,131.50,123.48,117.84,97.08,71.77,70.66,70.18,68.71,62.01,54.46$, 37.52, 29.30, 27.75, 20.73, 20.62. HRDARTMS: Calcd for $\mathrm{C}_{26} \mathrm{H}_{29} \mathrm{NO}_{11} \mathrm{~m} / \mathrm{z}$ 531.1735; [M + $\left.\mathrm{NH}_{4}\right]^{+} \mathrm{m} / \mathrm{z} 549.2098$ (calcd 549.2079).

Allyl 4,6-di-O-acetyl-2-deoxy-2-phthalimido- $\beta$-D-glucopyranoside (6). To a solution of 5 (552 $\mathrm{mg}, 1.04 \mathrm{mmol})$ in $95 \% \mathrm{EtOH}(30 \mathrm{~mL})$ and toluene $(10 \mathrm{~mL})$ was added hydrazine acetate $(11 \mathrm{mg}$, $0.122 \mathrm{mmol}$ ). The reaction was stirred at r.t. for $2 \mathrm{~h}$, after which time it was concentrated, and the residue was submitted to silica gel column chromatography $(1: 1$ hexane-EtOAc) to give compound 6 as a white solid (438 mg, 97\%). ${ }^{1} \mathrm{H}$ NMR $\left(300 \mathrm{MHz}, \mathrm{CDCl}_{3}\right): \delta 7.83-7.68(\mathrm{~m}, 4 \mathrm{H})$, $5.69(\mathrm{~m}, 1 \mathrm{H}), 5.23(\mathrm{~d}, J=8.4 \mathrm{~Hz}, 1 \mathrm{H}), 5.10(\mathrm{~d}, J=17.4 \mathrm{~Hz}, 1 \mathrm{H}), 5.03(\mathrm{~d}, J=11.1 \mathrm{~Hz}, 1 \mathrm{H}), 4.94$ $(\mathrm{t}, J=9.3 \mathrm{~Hz}, 1 \mathrm{H}), 4.41(\mathrm{t}, J=10.2 \mathrm{~Hz}, 1 \mathrm{H}), 4.32-4.14(\mathrm{~m}, 4 \mathrm{H}), 4.03(\mathrm{dd}, J=12.9 \mathrm{~Hz}, J=6.3$ $\mathrm{Hz}, 1 \mathrm{H}), 3.77(\mathrm{~m}, 1 \mathrm{H}), 2.82(\mathrm{bs}, 1 \mathrm{H}), 2.07(\mathrm{~s}, 6 \mathrm{H}) .{ }^{13} \mathrm{C} \mathrm{NMR}\left(75 \mathrm{MHz}, \mathrm{CDCl}_{3}\right): \delta 171.01,170.83$, $168.18,134.14,133.37,131.60,123.45,117.68,97.25,72.09,71.82,70.23,69.99,62.28,56.96$, 20.81, 20.74. HRDARTMS: Calcd for $\mathrm{C}_{21} \mathrm{H}_{23} \mathrm{NO}_{9} \mathrm{~m} / \mathrm{z}$ 433.1367; $\left[\mathrm{M}+\mathrm{NH}_{4}\right]^{+} \mathrm{m} / \mathrm{z} 451.1738$ (calcd 451.1711).

Allyl 2,3,4,6-tetra-O-acetyl-a-D-mannopyranosyl-(1 $\rightarrow 3)-4,6$-di-O-acetyl-2-deoxy-2-phthalimido$\boldsymbol{\beta}$-D-glucopyranoside (8). To a stirred suspension of 6 (209 $\mathrm{mg}, 0.483 \mathrm{mmol}), 2,3,4,6$-tetra-Oacetyl- $\alpha$-D-mannopyranosyl trichloroacetimidate $7(1.669 \mathrm{~g}, 3.40 \mathrm{mmol})$ and powdered $4 \AA$ molecular sieves $\left(200 \mathrm{mg}\right.$, activated at $\left.250{ }^{\circ} \mathrm{C}\right)$ in dry $\mathrm{CH}_{2} \mathrm{Cl}_{2}(20 \mathrm{~mL})$ was added TMSOTf $(20$ $\mu \mathrm{L})$ in $\mathrm{CH}_{2} \mathrm{Cl}_{2}(0.2 \mathrm{~mL})$ solution at $-30{ }^{\circ} \mathrm{C}$. The reaction was stirred under $\mathrm{N}_{2}$ for $1 \mathrm{~h}$ and warmed to r.t.. After stirring at r.t. for $4 \mathrm{~h}$ the reaction was quenched with TEA, filtered through Celite, concentrated and purified by silica gel column chromatography $\left(5: 1 \mathrm{CH}_{2} \mathrm{Cl}_{2}-\mathrm{EtOAc}\right)$ to give $\mathbf{8}$ (338 mg, 92\%) as a white solid. ${ }^{1} \mathrm{H}$ NMR (600 MHz, $\left.\mathrm{CDCl}_{3}\right): \delta 7.84-7.72(\mathrm{~m}, 4 \mathrm{H}), 5.62(\mathrm{~m}, 1 \mathrm{H})$, $5.29(\mathrm{t}, J=3.0 \mathrm{~Hz}, 1 \mathrm{H}), 5.22-5.05(\mathrm{~m}, 4 \mathrm{H}), 5.00(\mathrm{~m}, 1 \mathrm{H}), 4.75(\mathrm{~d}, J=2.1 \mathrm{~Hz}, 1 \mathrm{H}), 4.61(\mathrm{t}, J=$ $9.6 \mathrm{~Hz}, 1 \mathrm{H}), 4.30(\mathrm{~d}, J=8.4 \mathrm{~Hz}, 1 \mathrm{H}), 4.26-4.20(\mathrm{~m}, 3 \mathrm{H}), 4.08(\mathrm{~m}, 1 \mathrm{H}), 3.98(\mathrm{dd}, J=13.2 \mathrm{~Hz}, J$ $=6.6 \mathrm{~Hz}, 1 \mathrm{H}), 3.72(\mathrm{dd}, J=12.6 \mathrm{~Hz}, J=2.4 \mathrm{~Hz}, 1 \mathrm{H}), 3.69(\mathrm{~m}, 1 \mathrm{H}), 3.63(\mathrm{~d}, J=10.2 \mathrm{~Hz}, 1 \mathrm{H})$, $3.03(\mathrm{~d}, J=12.6 \mathrm{~Hz}, 1 \mathrm{H}), 2.12(\mathrm{~s}, 3 \mathrm{H}), 2.08(\mathrm{~s}, 3 \mathrm{H}), 2.04(\mathrm{~s}, 3 \mathrm{H}), 1.91(\mathrm{~s}, 3 \mathrm{H}), 1.90(\mathrm{~s}, 6 \mathrm{H}) .{ }^{13} \mathrm{C}$ NMR $\left(75 \mathrm{MHz}, \mathrm{CDCl}_{3}\right): \delta 170.77,170.22,169.85,169.59,169.42,169.38,134.52,133.13$, 131.36, 123.66, 117.89, 100.36, 97.01, 80.09, 71.93, 70.19, 69.99, 69.43, 69.41, 68.56, 64.94, 62.07, 61.08, 55.68, 20.77, 20.66, 20.63, 20.57, 20.53, 20.48. HRESIMS: Calcd for $\mathrm{C}_{35} \mathrm{H}_{41} \mathrm{NO}_{18}$ $\mathrm{m} / \mathrm{z}$ 763.2318; $\left[\mathrm{M}+\mathrm{NH}_{4}\right]^{+} \mathrm{m} / \mathrm{z} 781.2602$ (calcd 781.2662).

3-(2-Mercaptoethylthio)propyl 2,3,4,6-tetra-O-acetyl- $\alpha$-D-mannopyranosyl-( $\rightarrow 3$ )-4,6-di-Oacetyl-2-deoxy-2-phthalimido- $\beta$-D-glucopyranoside (9). To a stirred solution of 8 (264 mg, $0.346 \mathrm{mmol})$ in 1,4-dioxane $(10 \mathrm{~mL})$ was added 2-mercaptoethanethiol $(0.44 \mathrm{~mL}, \mathrm{mmol})$ and AIBN (15 mg). After stirring for $3 \mathrm{~h}$ at $75{ }^{\circ} \mathrm{C}$ under Ar, TLC (9:1 $\mathrm{CH}_{2} \mathrm{Cl}_{2}$-acetone) showed a complete conversion of the allyl glycoside into the adduct, and the reaction was quenched with cyclohexene $(0.3 \mathrm{~mL})$. After cooling to room temperature, the mixture was concentrated. Column chromatography (5:1 $\mathrm{CH}_{2} \mathrm{Cl}_{2}-$ EtOAc) of the residue yielded $9(251 \mathrm{mg}, 85 \%)$ as a white solid. ${ }^{1} \mathrm{H}$ NMR (300 MHz, $\left.\mathrm{CDCl}_{3}\right): \delta 7.88-7.76(\mathrm{~m}, 4 \mathrm{H}), 5.32(\mathrm{t}, J=3.3 \mathrm{~Hz}, 1 \mathrm{H}), 5.26-5.10(\mathrm{~m}, 2 \mathrm{H})$, $5.03(\mathrm{dd}, J=3.0 \mathrm{~Hz}, J=2.4 \mathrm{~Hz}, 1 \mathrm{H}), 4.79(\mathrm{~d}, J=2.1 \mathrm{~Hz}, 1 \mathrm{H}), 4.63(\mathrm{t}, J=9.9 \mathrm{~Hz}, 1 \mathrm{H}), 4.31-$ $4.24(\mathrm{~m}, 2 \mathrm{H}), 4.14(\mathrm{dd}, J=6.9 \mathrm{~Hz}, J=2.1 \mathrm{~Hz}, 1 \mathrm{H}), 4.10(\mathrm{dd}, J=6.9 \mathrm{~Hz}, J=2.1 \mathrm{~Hz}, 1 \mathrm{H}), 4.02$ 
(bs, $1 \mathrm{H}), 3.89(\mathrm{~m}, 1 \mathrm{H}), 3.77(\mathrm{dd}, J=12.6 \mathrm{~Hz}, J=2.7 \mathrm{~Hz}, 1 \mathrm{H}), 3.72(\mathrm{~m}, 1 \mathrm{H}), 3.66(\mathrm{~d}, J=9.3 \mathrm{~Hz}$, $1 \mathrm{H}), 3.50(\mathrm{~m}, 1 \mathrm{H}), 3.08(\mathrm{~d}, J=12.6 \mathrm{~Hz}, 1 \mathrm{H}), 2.51-2.46(\mathrm{~m}, 2 \mathrm{H}), 2.37-2.27(\mathrm{~m}, 2 \mathrm{H}), 2.15(\mathrm{~s}, 3 \mathrm{H})$, $2.11(\mathrm{~s}, 3 \mathrm{H}), 2.07(\mathrm{~s}, 3 \mathrm{H}), 1.95(\mathrm{~s}, 3 \mathrm{H}), 1.94(\mathrm{~s}, 3 \mathrm{H}), 1.93(\mathrm{~s}, 3 \mathrm{H}), 1.83-1.57(\mathrm{~m}, 4 \mathrm{H}) .{ }^{13} \mathrm{C}$ NMR $\left(75 \mathrm{MHz}, \mathrm{CDCl}_{3}\right): \delta 170.82,170.27,169.92,169.89,169.61,169.46,169.41,137.88,137.76$, $134.65,131.32,123.73,100.38,98.20,80.08,71.97,70.07,69.44,69.38,68.54,68.03,64.89$, $62.03,61.07,55.70,35.92,29.11,28.13,24.42,20.83,20.79,20.69,20.60,20.57,20.51$. HRDARTMS: Calcd for $\mathrm{C}_{37} \mathrm{H}_{47} \mathrm{NO}_{18} \mathrm{~S}_{2} \mathrm{~m} / \mathrm{z}$ 857.2234; [M] ${ }^{-} \mathrm{m} / \mathrm{z}$ 857.2230.

3-(2-Mercaptoethylthio)propyl $\quad 2,3,4,6$-tetra-O-acetyl- $\alpha$-D-mannopyranosyl-(1 $\rightarrow 3)$-2-acetamido-

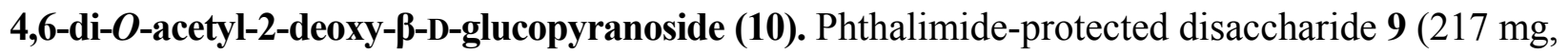
$0.253 \mathrm{mmol})$ was dissolved in $\mathrm{MeOH}(15 \mathrm{~mL})$ and ethylenediamine $(6.82 \mathrm{~mL}, 102 \mathrm{mmol})$ was added. The solution was then heated at reflux at $65^{\circ} \mathrm{C}$. After 2 days, TLC indicated the formation of a major product and complete consumption of the starting material. The reaction mixture was then cooled to r.t. and concentrated, and the residue was redissolved in pyridine $(9 \mathrm{~mL})$. The solution was cooled to $0{ }^{\circ} \mathrm{C}$ and $\mathrm{Ac}_{2} \mathrm{O}(7 \mathrm{~mL})$ was added. After 3 days, the reaction mixture was poured into ice water and extracted with $\mathrm{CH}_{2} \mathrm{Cl}_{2}$. The combined organic layers were washed with dilute aq $\mathrm{HCl}$ and satd aq $\mathrm{NaHCO}_{3}$, dried over anhyd $\mathrm{MgSO}_{4}$, filtered and evaporated to dryness. The residue was purified by silica gel column chromatography (100\% EtOAc) to afford 10 (121 $\mathrm{mg}, 62 \%)$ as a white solid. ${ }^{1} \mathrm{H}$ NMR $\left(600 \mathrm{MHz}, \mathrm{CDCl}_{3}\right): \delta 6.40(\mathrm{~d}, J=7.2 \mathrm{~Hz}, 1 \mathrm{H}), 5.24(\mathrm{t}, J=$ $10.2 \mathrm{~Hz}, 1 \mathrm{H}), 5.19$ (dd, $J=10.2 \mathrm{~Hz}, J=3.0 \mathrm{~Hz}, 1 \mathrm{H}), 5.02-4.99(\mathrm{~m}, 3 \mathrm{H}), 4.85(\mathrm{~s}, 1 \mathrm{H}), 4.47$ (t, $J$ $=9.6 \mathrm{~Hz}, 1 \mathrm{H}), 4.25-4.17(\mathrm{~m}, 3 \mathrm{H}), 4.09(\mathrm{dd}, J=12.0 \mathrm{~Hz}, J=3.6 \mathrm{~Hz}, 1 \mathrm{H}), 4.05(\mathrm{~s}, 1 \mathrm{H}), 4.04(\mathrm{dd}$, $J=8.4 \mathrm{~Hz}, J=4.8 \mathrm{~Hz}, 1 \mathrm{H}), 3.90(\mathrm{~m}, 1 \mathrm{H}), 3.64-3.57(\mathrm{~m}, 2 \mathrm{H}), 3.14(\mathrm{dd}, J=16.8 \mathrm{~Hz}, J=8.4 \mathrm{~Hz}$, 1H), 2.86-2.78 (m, 4H), 2.59 (t, J=7.2 Hz, 2H), 2.10 (s, 3H), 2.09 (s, 6H), $2.05(\mathrm{~s}, 3 \mathrm{H}), 2.01(\mathrm{~s}$, $3 \mathrm{H}), 1.98(\mathrm{~s}, 3 \mathrm{H}), 1.94(\mathrm{~s}, 3 \mathrm{H}), 1.89-1.78(\mathrm{~m}, 2 \mathrm{H}) .{ }^{13} \mathrm{C} \mathrm{NMR}\left(75 \mathrm{MHz}, \mathrm{CDCl}_{3}\right): \delta 171.06$, $170.77,169.85,169.73,169.70,169.56,99.28,99.21,79.93,71.43,70.10,69.62,68.81,68.41$, $68.17,66.71,63.25,62.20,58.13,38.35,31.22,29.38,28.40,23.64,20.77,20.65,20.54$. HRDARTMS: Calcd for $\mathrm{C}_{31} \mathrm{H}_{47} \mathrm{NO}_{17} \mathrm{~S}_{2} \mathrm{~m} / \mathrm{z} 769.2280$; [M - H] $]^{-} \mathrm{m} / \mathrm{z} 768.1979$ (calcd 768.2001).

3-(2-Mercaptoethylthio)propyl $\alpha$-D-mannopyranosyl-(1 $\rightarrow$ 3)-2-acetamido-2-deoxy- $\beta$-D-glucopyranoside (11). To a solution of $\mathbf{1 0}(116 \mathrm{mg}, 0.151 \mathrm{mmol})$ in dry $\mathrm{CH}_{2} \mathrm{Cl}_{2}(1 \mathrm{~mL})$ and dry $\mathrm{MeOH}(5 \mathrm{~mL})$ was added 6 drops of $\mathrm{NaOMe}(25 \%$ in $\mathrm{MeOH})$. The reaction was stirred at r.t. for $2 \mathrm{~h}$, after which time the reaction was neutralized with Dowex $50 \times 2-100\left(\mathrm{H}^{+}\right.$form). The suspension was filtered and evaporated to dryness. The residue was redissolved in water and submitted to Diaion HP-20 reversed-phase gel column chromatography. Water elution plus lyophilization and subsequent silica gel column chromatography $\left(1: 1 \mathrm{CH}_{2} \mathrm{Cl}_{2}-\mathrm{MeOH}\right)$ afforded $11(47 \mathrm{mg}, 60 \%)$ as a white solid, $[\alpha]_{\mathrm{D}}{ }^{25}+28^{\circ}\left(c \mathrm{c} 1.0, \mathrm{H}_{2} \mathrm{O}\right) .{ }^{1} \mathrm{H}$ NMR $\left(600 \mathrm{MHz}, \mathrm{D}_{2} \mathrm{O}\right): \delta 5.32(\mathrm{~s}, 1 \mathrm{H}), 4.58(\mathrm{~d}, J=8.4 \mathrm{~Hz}$, $1 \mathrm{H}), 4.05(\mathrm{t}, J=2.4 \mathrm{~Hz}, 1 \mathrm{H}), 4.02(\mathrm{~m}, 1 \mathrm{H}), 3.96(\mathrm{dd}, J=12.6 \mathrm{~Hz}, J=1.8 \mathrm{~Hz}, 1 \mathrm{H}), 3.89-3.72(\mathrm{~m}$, 7H), 3.65-3.60 (m, 2H), 3.51 (m, 1H), 3.39 (s, 1H), 3.00 (dd, $J=27 \mathrm{~Hz}, J=6.6 \mathrm{~Hz}, 1 \mathrm{H}), 3.03-$ $2.95(\mathrm{~m}, 3 \mathrm{H}), 2.72-2.64(\mathrm{~m}, 2 \mathrm{H}), 2.09(\mathrm{~s}, 3 \mathrm{H}), 1.95-1.87(\mathrm{~m}, 2 \mathrm{H}) .{ }^{13} \mathrm{C}$ NMR $\left(75 \mathrm{MHz}, \mathrm{D}_{2} \mathrm{O}\right): \delta$ $174.44,101.41,101.28,79.87,76.02,73.59,71.21,70.70,69.02,66.65,61.13,60.94,54.51$, 37.90, 30.40, 30.14, 29.00, 27.87, 22.91. MALDI-TOFMS: Calcd for $\mathrm{C}_{19} \mathrm{H}_{35} \mathrm{NO}_{11} \mathrm{~S}_{2} \mathrm{~m} / \mathrm{z}$ 517.1646; $[\mathrm{M}+\mathrm{Na}]^{+} \mathrm{m} / \mathrm{z} 540.1646($ calcd 540.1544). 


\section{Acknowledgments}

The financial support of the Natural Science Foundation of the Southwest University of Science and Technology is acknowledged. The authors are also grateful to Wen-bin Yang, Brian Sanders and Irene Abia for their laboratory assistance.

\section{References}

1. Varki, A. Glycobiology 1993, 3, 97.

2. Hakomori, S.-I. Pure Appl. Chem. 1991, 63, 473.

3. Hakomori, S.-I. Proc. Natl. Sci. USA 2002, 99, 225.

4. Rojo, J.; Morales, J. C.; Penadés, S. Top. Curr. Chem. 2002, 218, 45.

5. Barrientos, A. G.; de la Fuente, J. M.; Rojas, T. C.; Fernández, A.; Penadés, S. Chem. Eur. J. 2003, 9, 1909.

6. Benaissa-Trouw, B.; Lefeber, D. J.; Kamerling, J. P.; Vliegenthart, J. F. G.; Snippe, H.; Kraaijeveld, K. Infect. Immun. 2001, 69, 4698.

7. Andre, S.; Ortega, P. J.; Perez, M. A.; Roy, R.; Gabius, H.-J. Glycobiology 1999, 9, 1253.

8. Matsuura, K.; Kitakouji, H.; Sawada, N.; Ishida, H.; Kiso, M.; Kitajima, K.; Kobayashi, K. J. Am. Chem. Soc. 2000, 122, 7406.

9. de la Fuente, J. M.; Barrientos, A. G.; Rojas, T. C.; Roja, J.; Fernández, A.; Penadés, S. Angew. Chem. Int. Ed. 2001, 40, 2257.

10. Perrimon, N.; Bernfield, M. Nature 2000, 404, 725.

11. Otsuka, H.; Akiyama, Y.; Nagasaki, Y.; Kataoka, K. J. Am. Chem. Soc. 2001, 123, 8226.

12. Lin, C.-C.; Yeh, Y.-C.; Yang, C.-Y.; Chen, C.-L.; Chen, G.-F.; Chen, C.-C.; Wu, Y.-C. J. Am. Chem. Soc. 2002, 124, 3508.

13. Carvalho de Souza, A.; Halkes, K. M.; Meeldijk, J. D.; Verkleij, A. J.; Vliegenthart, J. F. G.; Kamerling, J. P. Eur. J. Org. Chem. 2004, 4323.

14. Lin, C.-C.; Yeh, Y.-C.; Yang, C.-Y.; Chen, G.-F.; Chen, Y.-C.; Wu, Y.-C.; Chen, C.-C. Chem. Commun.(Cambridge) 2003, 2920.

15. Halkes, K. M.; de Souza, A. C.; Maljaars, C. E. P.; Gerwig, G. J.; Kamerling, J. P. Eur. J. Org. Chem. 2005, 3650.

16. Schmidt, R. R.; Kinzy, W. Adv. Carbohydr. Chem. Biochem. 1994, 50, 21.

17. van Seeventer, P. B.; van Dorst, J. A. L. M.; Siemerink, J. F.; Kamerling, J. P.; Vliegenthart, J. F. G. Carbohydr. Res. 1997, 300, 369.

18. Misra, A. K.; Tiwari, P.; Madhusudan, S. K. Carbohydr. Res. 2005, 340, 325.

19. El-Sokkary, R. I.; Silwanis, B. A.; Nashed, M. A.; Paulsen, H. Carbohydr. Res. 1990, 203, 319.

20. Hasegawa, Y.; Kawada, T.; Kikkawa, Y.; Sakuno, T. Mokuzai Gakkaishi 1995, 41, 83. 
21. Slaghek, T. M.; Nakahara, Y.; Ogawa, T.; Kamerling, J. P.; Vliegenthart, J. F. G. Carbohydr. Res. 1994, 255, 61.

22. (a) Mori, T.; Hatano, K.; Matsuoka, K.; Esumi, Y.; Toone, E. J.; Terunuma, D. Tetrahedron 2005, 61, 2751. (b) Tosin, M.; Murphy, P. J. Org. Chem. 2005, 70, 4107.

23. Rising, T. W. D. F.; Claridge, T. D. W.; Davies, N.; Gamblin, D. P.; Moirb, J. W. B.; Fairbanks, A. J. Carbohydr. Res. 2006, 341, 1574. 